九州大学学術情報リポジトリ

Kyushu University Institutional Repository

\title{
Cost-Benefit Analysis of Food Firms Adopting HACCP System in Different Scales : A Case Study From China
}

Wang, Zhigang

School of Agricultural Economics and Rural Development, Renmin University of China

Weng, Yanzhen

School of Agricultural Economics and Rural Development, Renmin University of China

Yutaka, Tomoyuki

Faculty of Agriculture, Kyushu University

Fukuda, Susumu

Faculty of Agriculture, Kyushu University

他

https://doi.org/10.5109/9338

出版情報: 九州大学大学院農学研究院紀要. 52 (2)，pp.475-479，2007-10-29. Faculty of Agriculture, Kyushu University

バージョン :

権利関係 : 


\title{
Cost-Benefit Analysis of Food Firms Adopting HACCP System in Different Scales: A Case Study From China
}

\author{
Zhigang WANG ${ }^{1}$, Yanzhen WENG ${ }^{1}$, Tomoyuki YUTAKA ${ }^{2}$, \\ Susumu FUKUDA ${ }^{2}$ and Satoshi KAI ${ }^{2 *}$
}

\author{
${ }^{1}$ School of Agricultural Economics and Rural Development, Renmin University of China, PRC \\ ${ }^{2}$ Laboratory of Food Marketing, Division of Industrial Organization of Agribusiness, \\ Department of Agricultural and Resource Economics, Faculty of Agriculture, \\ Kyushu University, Fukuoka 812-8581, Japan \\ (Received June 30, 2007 and accepted July 17, 2007)
}

\begin{abstract}
Based on the data collected from a questionnaire survey of 344 food processing enterprises in China, applying simple quantitative analysis method, this paper mainly analyzes the cost and benefit of food firms in different scales after their HACCP adoption. It is found that after adopting HACCP, the before tax profit ratios appear negative in small-scale food processing firms, while they are positive in both medium-scale and large-scale ones. This study indicates that the diversity of firm scales make different effects on firms' before tax profit ratios after HACCP adoption. This result provides a forcible support for the claim that government should take necessary measures to help small-scale food processing firms adopt HACCP for preventing dangerous food safety hazards.
\end{abstract}

\section{INTRODUCTION}

Along with rapid economic growth, in China, the public are increasingly giving more attention to their living quality, and their food requirements have gradually been changing from "well fed" to "living like fighting cocks". Meanwhile, since China accessed to WTO in 2001, the green barrier has become a main obstacle against the export of agricultural products. Obviously, improving the quality of agricultural products is an urgent issue to China, and only by resolving it will it be possible for agricultural products to succeed in the world trade and to gain benefits from it finally. As a systematic approach to the identification, evaluation, and control of food safety hazards, HACCP or Hazard Analysis and Critical Control Point, which was introduced into China nearly twenty years ago, is now increasingly being used in food industry. Especially in recent years, China government and many food firms have given more and more attention to HACCP, and it is developing quite quickly.

HACCP is a system for analyzing food processing and identifying the undesirable/hazardous inclusion of chemical, physical or biological agents into food processing. It includes seven principles: conducting a hazard analysis, determining critical control points (CCP), establishing critical limits for each CCP, establishing a monitoring procedures for each CCP, establishing corrective actions, establishing verification procedures, and establishing document and record keeping procedures. Each food processing establishment is required to have its own HACCP plan tailored to its individual products. Moreover, there are required prerequisite programs (Good Manufacturing Practice, GMP) prior to the implementation of HACCP. As HACCP is increas-

\footnotetext{
* Corresponding author (E-mail: satokai@agr.kyushu-u.ac.jp)
}

ingly used as food safety assurance program, consumers have been put forward about its effectiveness in enhancing food safety as well as on the impacts it may have on industry.

There are several studies on the benefits and cost of HACCP regulation abroad, like Unnevehr and Jensen (1996), Antle (1996) and Crutchfield et al. (1997). But, up to the present, there are no references that focus on the influence of firms' profit or profit ratio in different firm scales after adopting HACCP in China. And previous studies on the HACCP system in China mainly focused on the flow process of HACCP and its application on relevant fields. For example, Wang and Li (2004) introduced the current conditions and existing problems in the process of introducing HACCP system into food industry and also put forward several suggestions for adopting HACCP in China. Bai, Ma and Gong (2005) analyzed the influences that the HACCP system brought to the food firms after they adopted HACCP certification. Zheng and Zhang (2004) showed the driving mechanism that motivates food firms to adopt HACCP system and emphasized that the type of food firms and external environment would affect the application of HACCP system. Wang, Mao and Chen (2006) used a hedonic price model to analyze the relationship between commodity prices and the HACCP certification label, and the result showed that the label has a positive and significant effect on the commodity prices.

Based on the background mentioned above, using an empirical analysis, this article is to explain the influence on food processing firms' before tax profits and before tax profit ratios in different food firm scales after adopting HACCP system. The rest of this paper is organized as follows: first, the overview of the data being used is presented; second, the cost-benefit of food processing firms in different scales after HACCP certification is analyzed; and third, the conclusions and suggestions are summarized. 


\section{Data}

A survey of food processing firms was conducted in China in late 2005, which was carried out by the Certification and Accreditation Administration of PRC. Of the 461 questionnaires collected, 117 were excluded because of incomplete replies; the remaining 344 questionnaires from implementing HACCP food firms were used in the present study. The content of the survey consisted of the knowledge that food processing firms possessing about the HACCP system, cost and benefit of firms after the adoption of HACCP certification, the main obstacles of implementing HACCP system which still exist in firms, and so forth. The responding firms include vegetable and aquatic products processing firms (accounting for $25.00 \%$ of all the 344 responding firms), beverage manufacturing firms $(20.06 \%)$, slaughtering and meat processing firms (18.02\%), relish and food additive firms (11.34\%), liquid milk and dairy products manufacturing firms $(9.30 \%)$, roast food and candy processing firms (9.01\%), and instant food and short-order firms $(7.27 \%)$

There are some indices to divide firms into different scales, such as firm personnel numbers, hardware equipments, firm annual sales value and so on. As the two formers are not considered in the survey, the annual sales value is the only scale index used to classify firms in this report. According to the Classification Standard of China from National Bureau of Statistics of China (NBSC), food processing firms whose annual sales values are less than 30 million RMB are small-scale firms, between 30 million RMB and 300 million RMB are medium-scale ones, and more than 300 million RMB are large-scale ones. According to the index of firm annual sales value, there are 91 small-scale firms (accounting for $26.45 \%$ of all the 344 responding firms), 174 medium-scale firms (50.58\%), and 79 large-scale firms (22.97\%), respectively, in the study.

Based on the survey, it showed that the major incentives of food processing firms' adopting HACCP system were enhancing the quality and safety of food products, improving the management level of firms, and the highly attention to food safety from leaders of food processing firms. And besides these, there are also included the present consumption fashion of pursuing healthy and safe food, the need of food processing firms to exploit the international market and to develop international trade, publicizing firms images, and increasing the discrepancy between the firms' own products and other homogeneous ones in the market. In the survey, the sampled firms were also asked whether they were confronted with any problems when adopting and implementing HACCP. Some sampled firms argued that they indeed faced with some obstacles such as the lack of relevant preferential policies from government, high certification fees and no unified HACCP standard. Then when asked about the necessity and efficiency of adopting HACCP certification, most surveyed firms believed that it was very necessary for them to implement HACCP system to boost economic benefits. Also, when asked whether they would keep the certification contin- ually, except for several firms that did not answer, nearly all the surveyed firms replied yes, indicating that HACCP system has been recognized by most food firms.

In order to adopt HACCP, food firms need to improve production equipments, to enhance environmental conditions and to train relevant staff, which would undoubtedly increase cost for them. However, once a firm implements HACCP system, it will bring abut many advantages, like arising the quality of food products, increasing satisfaction from consumers, and then increasing the sales of food firms. This study implies that the positive effects from HACCP exceed the negative ones as discussed below.

\section{COST-BENEFIT ANALYSIS OF IMPLEMENTING HACCP FIRMS IN DIFFERENT SCALES}

When using the same production equipments, employing coordinate qualified staff and other producing conditions, firms in different scales usually have different efficiency. Generally, larger firms may be much more efficient than smaller ones. What makes these differences? The major reason may be that some factors affecting production can create different effects on firms in different scales. Thus, as for the adoption of HACCP system, we can also predict that the cost and benefit of large-scale, medium-scale and small-scale firms would undoubtedly be different. The cost and benefit of food firms are studies in the three different scales as follows.

\section{Cost-benefit analysis of small-scale firms adopt- ing HACCP system}

Implementing HACCP system would cost expenses, including fees of rebuilding and improving production equipments, staff training fees, and testing fees. Table 1 shows the cost and benefit conditions of small-scale firms in each subdivided industry after adopting HACCP system. From the table, we can learn that, except the firms in roasted food and candy processing industry, the before tax profits and before tax profit ratios of firms in the rest industries are negative, especially those firms in instant food and short-order industry, and slaughtering and meat processing industry, which average before tax profit ratios are $-44.10 \%$ and $-24.26 \%$, respectively. Only the food processing firms in roast food and candy processing industry realize their positive before tax profits and before tax annual profit ratios, which are 0.3556 million RMB and 2.63\%. Therefore, for small-scale firms, after obtaining HACCP system, it is because of high investment input and non-synchronous increasing sales values, which results in most of them being in deficit, and their before tax profit ratios appear negative. Nevertheless, some food processing firms in small-scale argue that their maximal yields from adopting HACCP lie in increasing the degree of the firms' fame and boost their market shares.

\section{Cost- benefit analysis of medium-scale firms adopting HACCP system}


Compared with small-scale firms, the scale and strength of medium-scale firms are much larger, in the same way, the effects caused by adopting HACCP on the medium-scale firms is also bigger than small-scale ones.
Table 2 shows the cost and benefit analysis of medium-scale firms in subdivided industries after going through HACCP certification. Its calculating methods of the before tax profits and before tax profit ratios are the

Table 1. Cost-benefit estimations of 91 small-scale firms implementing HACCP in subdivided industries in ten thousand RMB

\begin{tabular}{|c|c|c|c|c|c|c|c|}
\hline Items & $\begin{array}{l}\text { Vegetable } \\
\text { and aquatic } \\
\text { products } \\
\text { Processing } \\
\text { industry }\end{array}$ & $\begin{array}{l}\text { Instant food } \\
\text { and } \\
\text { short-order } \\
\text { industry }\end{array}$ & $\begin{array}{l}\text { Slaughterin } \\
\text { g and meat } \\
\text { processing } \\
\text { industry }\end{array}$ & $\begin{array}{c}\text { Beverage } \\
\text { manufacturi } \\
\text { ng industry }\end{array}$ & $\begin{array}{c}\text { Relish and } \\
\text { food } \\
\text { additive } \\
\text { industry }\end{array}$ & $\begin{array}{c}\text { Liquid milk } \\
\text { and dairy } \\
\text { products } \\
\text { industry }\end{array}$ & $\begin{array}{c}\text { Roast food } \\
\text { and candy } \\
\text { processing } \\
\text { industry }\end{array}$ \\
\hline Number of firms & 30 & 12 & 11 & 15 & 14 & 2 & 7 \\
\hline Annual sales values (1) & 1634.81 & 1477.00 & 1368.33 & 1800.00 & 1732.70 & 1297.50 & 1350.50 \\
\hline Production Cost (2) & 1226.81 & 785.00 & 1054.18 & 1203.28 & 1359.60 & 1033.50 & 916.50 \\
\hline Sales Expense (3) & 75.07 & 146.00 & 40.34 & 564.50 & 138.82 & 195.50 & 91.60 \\
\hline Wages expenditure (4) & 123.90 & 262.29 & 93.33 & 65.11 & 133.86 & 220.50 & 159.30 \\
\hline Investment of basic equipment (5) & 249.90 & 935.00 & 512.50 & 170.32 & 314.49 & 18.00 & 147.54 \\
\hline $\begin{array}{l}\text { Before tax annual profit } \\
(6)=(1)-(2)-(3)-(4)-(5)\end{array}$ & -40.87 & -651.29 & -332.02 & -203.21 & -214.07 & -170.00 & 35.56 \\
\hline $\begin{array}{l}\text { Before tax annual profit ratio } \\
(7)=(6) /(1) * 100 \%\end{array}$ & $-2.50 \%$ & $-44.10 \%$ & $-24.26 \%$ & $-11.29 \%$ & $-12.35 \%$ & $-13.10 \%$ & $2.63 \%$ \\
\hline
\end{tabular}

NOTE. This production cost does not include investment of basic equipment. And wages expenditure includes two parts, wages expenditure of production and of sales, which are not counted into production cost and sales expenditure, respectively.

Table 2. Cost-benefit estimations of 174 medium-scale firms implementing HACCP in subdivided industries in ten thousand RMB

\begin{tabular}{|c|c|c|c|c|c|c|c|}
\hline Items & $\begin{array}{c}\text { Vegetable } \\
\text { and aquatic } \\
\text { products } \\
\text { processing } \\
\text { industry }\end{array}$ & $\begin{array}{l}\text { Instant food } \\
\text { and } \\
\text { short-order } \\
\text { industry }\end{array}$ & $\begin{array}{l}\text { Slaughterin } \\
\text { g and meat } \\
\text { processing } \\
\text { industry }\end{array}$ & $\begin{array}{c}\text { Beverage } \\
\text { manufacturi } \\
\text { ng industry }\end{array}$ & $\begin{array}{c}\text { Relish and } \\
\text { food } \\
\text { additive } \\
\text { industry }\end{array}$ & $\begin{array}{c}\text { Liquid milk } \\
\text { and dairy } \\
\text { products } \\
\text { industry }\end{array}$ & $\begin{array}{c}\text { Roast food } \\
\text { and candy } \\
\text { processing } \\
\text { industry }\end{array}$ \\
\hline Number of firms & 48 & 10 & 27 & 34 & 18 & 17 & 20 \\
\hline Annual sales values (1) & 8426.18 & 5450.83 & 12124.26 & 13945.36 & 12227.90 & 15764.65 & 8247.00 \\
\hline Production Cost (2) & 5554.77 & 3749.30 & 9054.00 & 7523.96 & 8649.85 & 6081.05 & 6245.42 \\
\hline Sales Expense (3) & 269.23 & 211.83 & 289.29 & 2297.54 & 453.65 & 2338.70 & 851.22 \\
\hline Wages Expenditure (4) & 553.93 & 469.30 & 420.54 & 1826.39 & 478.39 & 518.84 & 507.33 \\
\hline Investment of basic equipment (5) & 820.24 & 823.76 & 458.72 & 1552.17 & 572.22 & 2668.35 & 432.00 \\
\hline $\begin{array}{l}\text { Before tax annual profit } \\
(6)=(1)-(2)-(3)-(4)-(5)\end{array}$ & 1228.01 & 196.64 & 1901.71 & 745.30 & 2073.79 & 4157.71 & 211.03 \\
\hline $\begin{array}{l}\text { Before tax annual profit ratio } \\
(7)=(6) /(1) * 100 \%\end{array}$ & $14.57 \%$ & $3.61 \%$ & $15.69 \%$ & $5.34 \%$ & $16.96 \%$ & $26.37 \%$ & $2.56 \%$ \\
\hline
\end{tabular}

NOTE. The same as Table 1 .

Table 3. Cost-benefit estimations of 79 large-scale firms implementing HACCP system in subdivided industries in ten thousan RMB

\begin{tabular}{|c|c|c|c|c|c|c|c|}
\hline Items & $\begin{array}{c}\text { Vegetable } \\
\text { and aquatic } \\
\text { products } \\
\text { processing } \\
\text { industry }\end{array}$ & $\begin{array}{l}\text { Instant food } \\
\text { and } \\
\text { short-order } \\
\text { industry }\end{array}$ & $\begin{array}{l}\text { Slaughterin } \\
\text { g and meat } \\
\text { processing } \\
\text { industry }\end{array}$ & $\begin{array}{c}\text { Beverage } \\
\text { manufacturi } \\
\text { ng industry }\end{array}$ & $\begin{array}{c}\text { Relish and } \\
\text { food } \\
\text { additive } \\
\text { industry }\end{array}$ & $\begin{array}{c}\text { Liquid milk } \\
\text { and dairy } \\
\text { products } \\
\text { industry }\end{array}$ & $\begin{array}{c}\text { Roast food } \\
\text { and candy } \\
\text { processing } \\
\text { industry }\end{array}$ \\
\hline Number of firms & 8 & 3 & 24 & 20 & 7 & 13 & 4 \\
\hline Annual sales values (1) & 46696.00 & 22749.50 & 170778.30 & 66726.00 & 38500.00 & 112152.30 & 65000.00 \\
\hline Production cost (2) & 22924.00 & 6846.46 & 146818.90 & 26699.67 & 30541.00 & 36995.33 & 25750.00 \\
\hline Sales expense (3) & 3056.40 & 854.00 & 5019.85 & 12998.50 & 536.00 & 13048.47 & 300.00 \\
\hline Wages expenditure (4) & 1994.60 & 477.00 & 2734.93 & 4102.00 & 915.00 & 5498.77 & 1100.00 \\
\hline Investment of basic equipment (5) & 7755.50 & 1800.00 & 8123.36 & 3993.44 & 333.50 & 5244.06 & 500.00 \\
\hline $\begin{array}{l}\text { Before tax annual profit } \\
(6)=(1)-(2)-(3)-(4)-(5)\end{array}$ & 10965.50 & 12772.04 & 8081.25 & 18932.39 & 6174.50 & 51365.67 & 37350.00 \\
\hline $\begin{array}{l}\text { Before tax annual profit ratio } \\
(7)=(6) /(1) * 100 \%\end{array}$ & $23.48 \%$ & $56.14 \%$ & $4.73 \%$ & $28.37 \%$ & $16.04 \%$ & $45.80 \%$ & $57.46 \%$ \\
\hline
\end{tabular}

NOTE. The same as Table 1. 
same with small-scale firms as we show in Table 1. From Table 2, we can know that all of the medium-scale firms $(\mathrm{N}=174)$ gain positive profits, and the before tax profit ratios of the firms in vegetable, fishery, slaughtering, meat processing, spice, food additive, liquid milk and dairy manufacturing industries have reached more than ten percent, making a sharp comparison with the small-scale firms.

\section{Cost-benefit analysis of large-scale firms adopt- ing HACCP system}

From the above results, most small-scale firms gain negative profits and all medium-scale firms obtain positive profits, thus for the profits of large-scale firms implementing HACCP, we can make a simple prediction that all the large-scale food processing firms also may gain positive profits. Table 3 has proved this expectation. Its calculation methods of before tax profits and before tax profit ratios are also the same with small-scale and medium-scale firms. From table 3, we can learn that all the large-scale firms adopting HACCP can gain positive before tax profits and, except the firms in the slaughtering and meat processing industry, the before tax profit ratios of the firms also reached more than ten percent. This is especially true for firms in instant food and short-order, milk and dairy processing, and roasted food and candy roasted industries, which before tax profit ratios are 56.14\%, 45.80\% and 57.46\%, respectively, after adopting HACCP. The survey results show that the main advantages of implementing HACCP in large-scale firms are to increase product exports, to enhance market share, and to improve the level of management, which would directly and indirectly increase the firms' turnover.

\section{Cost-benefit analysis of all the sampled firms in different scales}

From the above analysis, we can draw a rough picture with the cost and benefit of three scales of firms after adopting HACCP system. We now describe these three scales firms as a whole, using two methods, arithmetical average method and weighted average method.

By comparison with the method of arithmetical average, there are many advantages of weighted average method. For this study, the most direct advantage is that it endows each subdivided industry with different weights, thus taking the discrepancy of different industries into consideration if each subdivided industry would affect the concrete value of each index. In a certain extent, the weighted average method could come true the effect, and the gained data would be more correctly used.

Table 4 uses these two methods to estimate the before tax profits and before tax profit ratios of different scales firms. From the Table, we can see that there is a remarkable difference in the cost-benefit among each scale of firms after adopting HACCP certification system, and we also learn that by either using arithmetical average method or using weighted average method, the figures of the before tax profits and before tax profit ratios in the three scales firms are quite approximate. In general, the before tax profit ratios in small-scale firms are negative, between $-14.78 \%$ and $-12.97 \%$. Correspondingly, in medium-scale firms and large-scale firms, the before tax profit ratios are between 13.06\% and $13.80 \%$, between $5.31 \%$ and $5.63 \%$, respectively. These results indicate that small-scale firms are in deficit, the before tax profit ratios in large-scale firms are positive and the biggest among the three scales firms when adopted HACCP. According to the data from

Table 4. Cost-benefit analysis of all the sampled firms in different scales in ten thousand RMB

\begin{tabular}{|c|c|c|c|c|c|c|}
\hline \multirow{2}{*}{ Items } & \multicolumn{3}{|c|}{ Arithmetical average } & \multicolumn{3}{|c|}{ Weighted average } \\
\hline & Small-scale & Medium-scale & Large-scale & Small-scale & Medium-scale & Large-scale \\
\hline Number of firms & 91 & 174 & 79 & 91 & 174 & 79 \\
\hline Annual average sales values (1) & 1522.98 & 10883.74 & 74657.44 & 1594.79 & 10997.15 & 99525.26 \\
\hline Variable cost (2) & 1412.71 & 8334.93 & 49887.27 & 1445.88 & 8543.71 & 74540.53 \\
\hline Marginal income $(3)=(1)-(2)$ & 110.27 & 2548.81 & 24770.17 & 148.91 & 2453.44 & 24984.73 \\
\hline Fixed cost (4) & 335.39 & 1046.78 & 3964.27 & 355.83 & 1017.65 & 5605.14 \\
\hline $\begin{array}{l}\text { Before tax annual profit } \\
(5)=(3)-(4)\end{array}$ & -225.12 & 1502.03 & 20805.90 & -206.92 & 1435.79 & 19734.35 \\
\hline $\begin{array}{l}\text { Variable cost ratio } \\
(6)=(2) /(1) * 100 \%\end{array}$ & $92.76 \%$ & $76.58 \%$ & $66.82 \%$ & $90.66 \%$ & $77.69 \%$ & $74.90 \%$ \\
\hline $\begin{array}{l}\text { Marginal income ratio } \\
(7)=(3) /(1) * 100 \%\end{array}$ & $7.24 \%$ & $23.42 \%$ & $33.18 \%$ & $9.34 \%$ & $22.31 \%$ & $25.10 \%$ \\
\hline $\begin{array}{l}\text { Fixed cost ratio } \\
(8)=(4) /(1) * 100 \%\end{array}$ & $22.02 \%$ & $9.62 \%$ & $5.31 \%$ & $22.31 \%$ & $9.25 \%$ & $5.63 \%$ \\
\hline $\begin{array}{l}\text { Before tax annual profit ratio } \\
(9)=(5) /(1) * 100 \%\end{array}$ & $-14.78 \%$ & $13.80 \%$ & $19.83 \%$ & $-12.97 \%$ & $13.06 \%$ & $19.83 \%$ \\
\hline $\begin{array}{l}\text { Break-even point } \\
(10)=(4) /(7)\end{array}$ & 4632.46 & 4469.60 & 11947.77 & 3809.74 & 4561.41 & 22331.27 \\
\hline $\begin{array}{l}\text { Degree of operating safety } \\
(11)=(1)-(10) /(1) * 100 \%\end{array}$ & $-204.17 \%$ & $58.93 \%$ & $84.00 \%$ & $-138.89 \%$ & $58.52 \%$ & $77.56 \%$ \\
\hline
\end{tabular}

NOTE. The same as Table 1. 
China Statistical Yearbook 2005, the general before tax profit ratio of the China food manufacture industry in 2005 is $4.9 \%$. And either through the approach of arithmetical average or weighted average, the before tax profit ratios of large-scale and medium-scale firms that adopt the HACCP system are far higher than the average level of the whole food manufacture industry.

We calculated the break-even point and found that the annual average sales values are less than the break-even point, the difference is 31.0938 million RMB. We also calculated the degree of operating safety, and it was showed that the degree of operating safety is minus. This indicates that the small-scale firms are in dangers Compared to the small-scale firms, the degree of operating safety of medium-scale firms and large-scale firms are increasing gradually.

\section{CONCLUSIONS AND SUGGESTIONS}

HACCP has obtained recognition from most factories and consumers as it rapid develops in China. We believe that, after its ten years advancement and with the public increasing concern for food quality and safety, the efficiency of HACCP will be gradually recognized by many social communities since it provides a powerful safeguard for our food safety. From the above data analysis, we can draw several conclusions:

First, from the perspective of the whole food processing manufacture industry, the positive effects brought from the HACCP system is much higher than the negative ones, this proves that the HACCP system is cost-benefit effective. second, although the whole industry can gain profit, it is minimal for small-scale firms where all of their profits are nearly negative; third, the profit ratios of medium-scale ones are basically at the average level in the industry and large-scale ones get the highest profit ratios; fourth, because of the difference of market shares, the benefits from HACCP are inevitably different among different firms since the products of small-scale firms are not well-known and popular; after the certification, the reputation of the products can be enhanced by such approaches as increasing publicization. Medium-scale firms can increase the market shares and the produce reputation. For large firms, while possessing considerable sales volume, the certification may powerfully support the products' export and gain much more profit.

On the basis of the above conclusions, we present some suggestions below:

First, among the firms adopting the HACCP food safety management system in China, although there many small-scale firms, the proportion of them to the total number of firms is quite low. So, relevant govern- ment departments should carry out research on the small-scale firms, actively take efficient political measures, and provide preferential policies such as offering funds in order to promote small-scale ones to enhance the management of food quality and safety; second, after certification, most small-scale firms cannot survive. Therefore, government should further support the development of those firms and create good environment for their survival under the market economic situation; third, government should increase the education of food safety to producers and consumers; advance the extent of market recognition of the HACCP system; and cultivate consumers' consciousness of food safety; fourth, market access of food quality and safety should be strictly implemented; the level of domestic food firms' supervision should be raised; and the enthusiasm of domestic food firms in enhancing produce quality management of domestic food firms should be promoted.

\section{ACKNOWLEDGMENT}

The authors gratefully acknowledge financial support from Beijing Natural Science Foundation (No. 9062007), and National Natural Science Foundation of China (No. 70473095).

\section{REFERENCES}

Antle, J. M. 1996 Efficient Food Safety Regulation in the Food Manufacturing Sector. American Journal of Agricultural Economics, 78(5): 1242-1247

Bai, Li, Ma, Chengli and Gong, Shunlong 2005 An Empirical Study of Chinese Food Firms Implementing HACCP Food Safety Management System. Science and Technology of Food Industry, 9: 16-18 (in Chinese)

Crutchfield, S., J. Buzby, P. Frenzen, J. Allshouse, and D. Roberts 2000 The Economics of Food Safety and Internation Trade in Food Products. Paper Presented at the International Institute of Fisheries Economics and Trade (IIFET) Conference

Unnevehr, L. J. and Jensen, H. H 1996 HACCP as a Regulatory Innovation to Improve Food Safety in the Meat Industry. American Journal of Agricultural Economics, 78: 764-769

Wang, Zhigang and Li, Yan 2004 Present Situation and Problems of HACCP-adoption in Food-processing Firms. The Symposium of National Food Safety Forum (Beijing), 11: 530-546 (in Chinese)

Wang, Zhigang, Mao, Yanna and Chen, Chuanbo 2006 Whether the Label of HACCP Certification Affects a Commodity's Price?-An Investigation of Milk Products from Six Supermarkets in Haidian District in Beijing. China Soft Science, 4: 75-82 (in Chinese)

Zheng, Fengtian and Zhang, Ying 2004 A Research on the Driving Force for Chinese Food Enterprises Adopting HACCP System. The Symposium of National Food Safety Forum (Beijing), 11: 495-521 (in Chinese) 